Mosul Journal of Nursing, Vol. 7, No. 2, 2019 ( 63-74 )

Mosul Journal of Nursing

www.mjn.mosuljournals.com

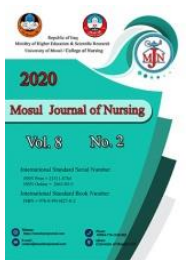

\title{
Effect of cochlear implants in chidren on parental mental health in
}

\section{Mousl city}

Article information

Article history:

Received April 21, 2019

Accepted July 24, 2019

Available online July 31, 20191

DOI: $\frac{10.33899 / \mathrm{min} .2019 .162876}{\text { Creative Commons Attribution 4.0 International License }}$

Ahmed Abdulla Aziz, Alsamady

\begin{abstract}
:
Cochlear implant is one of the treatments for deafness.

child cochlear, purpsive sample their children have (CI) from hearing and speech rehabilitation centers in Mousl city. During a peroid 10 january 2018 to 28 february 2019. The instrument depended in the study was 28-GHQ self- administered technique. The GHQ-28 is divided into four categories: somatic symptoms, anxiety/insomnia, social dysfunction and depression.

This questionnaire includes information about the operated child such as gender, age, date of birth, and also information about the parents, such as their age, job and family background

.Data were analyzed in several steps. First descriptive statistics, which include frequency

and percentages. The second step, which include inferential statistics Chi-Square test) ,the probability level depend in the present study was $\mathrm{p}<0.05$

the study concluded Mother and father were affected by psychological symptoms.

the study recommended Preparing a comprehensive extension program that is suitable for the size of the problem experienced by parents and families through psychological, social and financial support programs, participation of specialists and professionals, families of children with hearing. disabilities, and the development of suitable solutions for themdeveloping a child's language helps parents get rid of their anxiety, Provide advanced rehabilitation centers within the governorate and be more than a center rehabilitation and training of staff working in the centers of rehabilitation, Make the parents communicate fully with the manufacturers of the cochlear and make the center of the company in each province, providing the spare tools for planting Working on the opening of specialized centers for cochlear implantation to reduce cost.
\end{abstract}

\footnotetext{
${ }^{1}$ MS.c in nursing/High institute of heath in mousl
} 


\section{Mosul Journal of Nursing, Vol. 7, No. 2, 2019 ( 63-74 )}

\section{$\underline{\text { Introduction }}$}

No parents want to imagine that their baby would be born with any physical or mental disorder. However about 2 or 3 in every 1000 babies are born with a birth defect (Garry VF ,2002).

In Iraq ten years ago began cochlear implants in hospitals in Baghdad.(alkarkh ,health directrate bagdad web,2018) while in the city of Sulaymaniyah, has been planted 200 cochlea since the start of the program and the number is increasing (alwaten, news paper, 2016).

Approximately 1200 people receive a cochlear implant in the United kingdom each year. (BCIG,2015).

A child who does not hear increases the signs and symptomes risk for parents, a cochlear implant (CI) is a prosthesis for the hair cells in inside the ear (inner ear area) with plain or profound hearing absence. In children with a plain or deep sensorineural hearing impairment it usually allows the expansion of speech understanding and production of talk (Beadle et al., 2005)

Psychological and mental health is one of the most important indicators of wellbeing and health in any society, whether urban or rural . In a modern reserch by the American Psychiatric Association (APA), it was shown that psychological health the study identified feature that make up psychological health called "positive psychology" is more than the absence of mental disease. (Holmes, 2003). Humans may face many difficulties upon depriving from this grace (WHO) Has made the family the first factor in achieving wellbeing and improvment health care. Family welfare refers to the sense of well-being of the family which we can identify individually from the same person or society collectively and in which the needs of the individual and individual and the situation of the family in terms of cultural and social and economic family is the nucleus in the formation of communities and one of the reasons that the community feel comfortable and stable. ( Zuna, N, 2010). Couples are in focus as the main core of family. Health and dynamics of family relies on health and happiness of couples. Couples can be regarded as the driving force of the family. Among the most important features of a balanced family, is the ability to face the world positively and formatively. So People pay attention to positive, informative and inspiring aspects of a phenomenon especially when they encounter problems, and disregard negative points (Seligman, 2001) Therefore the factors leading to stability of this social focal point may indirectly bring about balance and firmness to the society. So far, many factors have been reported to influence the stability and marital satisfaction within families including having mental health, showing logical and rational reactions towards life's problems, (Besharat et al, 2006), mutual understanding in life (Mirahmadizadeh et al, 2003), and not having psychiatric disorders (Overbeek et al, 2006). Disability is part of the human condition. Almost everyone will be temporarily or permanently impaired at some point in life, and those who survive to old age will experience 


\section{Mosul Journal of Nursing, Vol. 7, No. 2, 2019 ( 63-74 )}

increasing difficulties in functioning. Most extended families have a disabled member, and many non-disabled people take responsibility supporting and caring for their relatives and friends with disabilities( Mishra AK, 2006). It limits the ability of the individual to perform one or more of the functions that are essential in daily life, such as self-care, social interaction and economic activities, within the limits that are natural. Or the inability to obtain self-sufficiency and to make it in constant need of the aid of others, and to a special education to help him overcome his disability. ( Leonardi $\mathrm{M}$ et al,2006).

The term auditory disability is a general term used to distinguish any

An individual suffering from hearing loss regardless of the degree of auditory impairment, who suffer from it.(alsherbeni,Z,2004)

Various studies refer to the stressfulness of diagnosing deafness and the operation of cochlear implant in children. For instance, a study done on 24 mothers in India suggested that mothers whose children underwent cochlear implant, experience more stress than those whose children have normal hearing. (Filipo et al, 1997). In another study done on 87 parents in Germany, those whose children were candidates for cochlear implant, experienced $29 \%$ more stress during their child's recovery period (Richter et al, 2000). Additionally other studies show decreasing life quality in the parents of deaf children upon hearing about their child's defects Burger et al, 2002). Another study 29 parents of deaf children who were referred to Baghiatallah Hospital for cochlear implant, The results show that doing the operation of cochlear implant for children can have a significant positive effect on the general health of the parents of those deaf children, which is indicative of mental health.( Fatemeh Saghafi,2013).

Mothers of deaf, (CI) using children experience significantly more symptoms of anxiety and insomnia compared to the mothers of typically developing children, while fathers of these children show the tendency for the increased level of depression symptoms compared to the fathers from the control group(kobosko,J,2014). A nother study study of 18 people in the testing of parents' experiences with children with deafness in different stages of life showed that parents should be informed of the challenges and difficulties parents will face.(Mary Flaherty,2015)

\section{Methods and materials :}

A descrptive study was conducted for parents to 48 who have child cochlear, purpsive sample their children have (CI) from hearing and speech rehabilitation centers in Mousl city. During a peroid 10 january 2018 to 28 february 2019 . The instrument depended in the study was 28-GHQ .

The General Health Questionnaire (GHQ) is a common form of assessment of mental wellbeing. The questionnaire was developed by Goldberg in 1972 as a tool to examine people who are likely to be at risk of mental disorders 


\section{Mosul Journal of Nursing, Vol. 7, No. 2, 2019 ( 63-74 )}

in various modified versions using $12,28,30$ or 60 items. The version used in this study is a questionnaire form 28 paragraphs for the purpose of detecting mental disorders, which is the most widely used questionnaire, is also used in this research. The GHQ-28 is divided into four categories: somatic symptoms, anxiety/insomnia, social dysfunction and depression (Goldberg \& Hillier, 1979)

This questionnaire includes information about the operated child such as gender, age,

\section{Results}

\section{Tabl-1 Demographic Characteristics for child}

\begin{tabular}{|c|l|l|l|}
\hline \multicolumn{2}{|l|}{ Demographic data for child } & No. & $\%$ \\
\hline \multirow{4}{*}{ gender } & male & 22 & $46 \%$ \\
\cline { 2 - 4 } & female & 26 & $54 \%$ \\
\hline \multirow{4}{*}{ age } & under 3 years & 12 & $\%$ \\
\cline { 3 - 5 } & $3-5$ years & 10 & $25 \%$ \\
\cline { 2 - 4 } & above 5 years & 26 & $21 \%$ \\
\hline \multirow{4}{*}{ child in family } & first child & 17 & $54 \%$ \\
\cline { 2 - 4 } & second child & 20 & $35 \%$ \\
\cline { 2 - 4 } & third child & 11 & $42 \%$ \\
\hline
\end{tabular}

Table -2 Demographic Characteristics for Father \& Mother

\begin{tabular}{|c|c|c|c|}
\hline \multirow{9}{*}{ Father } & The Work & No. & $\%$ \\
\hline & worker & 23 & $48 \%$ \\
\hline & Civil Servant & 17 & $35 \%$ \\
\hline & Unemployed & 8 & $17 \%$ \\
\hline & & & \\
\hline & Age & No. & $\%$ \\
\hline & under 25 & 9 & $19 \%$ \\
\hline & $25-30$ & 27 & $56 \%$ \\
\hline & above 30 & 12 & $25 \%$ \\
\hline
\end{tabular}


Mosul Journal of Nursing, Vol. 7, No. 2, 2019 ( 63-74 )

\begin{tabular}{|l|l|l|l|}
\hline \multicolumn{4}{|l|}{} \\
\hline \multirow{5}{*}{ Mother } & The Work & No. & $\%$ \\
\cline { 2 - 4 } & students & 4 & $8 \%$ \\
\cline { 2 - 4 } & house wife & 31 & $65 \%$ \\
\cline { 2 - 4 } & Civil Servant & 13 & $27 \%$ \\
\cline { 2 - 4 } & \multicolumn{2}{|l|}{} \\
\cline { 2 - 4 } \multicolumn{2}{|c|}{ Age } & No. & $\%$ \\
\cline { 2 - 4 } & under 25 & 25 & $52 \%$ \\
\cline { 2 - 4 } & $25-30$ & 16 & $33 \%$ \\
\cline { 2 - 4 } & above 30 & 7 & $15 \%$ \\
\hline
\end{tabular}

Table -3 somatic symptoms (GHQ-A) for father and mother

\begin{tabular}{|c|c|c|c|c|c|c|c|c|c|c|c|}
\hline SOMATIC symptomes & & No. & $\%$ & No. & $\%$ & No. & $\%$ & No. & $\%$ & $\mathbf{X}^{2}$ & $\begin{array}{l}\mathbf{P}_{-} \\
\text {Value }\end{array}$ \\
\hline \multirow{2}{*}{$\begin{array}{l}\text { 1- Been feeling perfectly well and in } \\
\text { good health? }\end{array}$} & Father & 12 & $25 \%$ & 31 & $65 \%$ & 4 & $8 \%$ & 1 & $2 \%$ & \multirow[t]{2}{*}{4.676} & \multirow{2}{*}{$\begin{array}{l}0.197 \\
(\mathrm{NS})\end{array}$} \\
\hline & Mother & 9 & $18 \%$ & 27 & $56 \%$ & 6 & $13 \%$ & 6 & $13 \%$ & & \\
\hline \multirow{2}{*}{$\begin{array}{l}\text { 2- Been feeling in need of a good } \\
\text { tonic? }\end{array}$} & Father & 32 & $67 \%$ & 8 & $17 \%$ & 5 & $10 \%$ & 3 & $6 \%$ & \multirow[t]{2}{*}{35.479} & \multirow[t]{2}{*}{$0.000 *$} \\
\hline & Mother & 8 & $17 \%$ & 10 & $21 \%$ & 30 & $62 \%$ & 0 & $0 \%$ & & \\
\hline \multirow{2}{*}{$\begin{array}{l}\text { 3- Been feeling run down and out of } \\
\text { sorts? }\end{array}$} & Father & 7 & $15 \%$ & 13 & $27 \%$ & 18 & $38 \%$ & 10 & $21 \%$ & \multirow[t]{2}{*}{0.789} & \multirow{2}{*}{$\begin{array}{l}0.852 \\
(\mathrm{NS})\end{array}$} \\
\hline & Mother & 7 & $15 \%$ & 11 & $23 \%$ & 22 & $46 \%$ & 8 & $16 \%$ & & \\
\hline \multirow[t]{2}{*}{ 4- Felt that you are ill? } & Father & 14 & $29 \%$ & 16 & $33 \%$ & 10 & $21 \%$ & 8 & $17 \%$ & \multirow[t]{2}{*}{0.260} & 0.967 \\
\hline & Mother & 12 & $25 \%$ & 16 & $33 \%$ & 11 & $23 \%$ & 9 & $19 \%$ & & (NS) \\
\hline \multirow{2}{*}{$\begin{array}{l}\text { 5-Been getting a feeling of thghtness } \\
\text { or pressure in your head? }\end{array}$} & Father & 6 & $13 \%$ & 5 & $10 \%$ & 35 & $73 \%$ & 2 & $4 \%$ & \multirow[t]{2}{*}{1.966} & \multirow{2}{*}{$\begin{array}{l}0.579 \\
(\mathrm{NS})\end{array}$} \\
\hline & Mother & 6 & $13 \%$ & 2 & $4 \%$ & 36 & $75 \%$ & 4 & $8 \%$ & & \\
\hline \multirow{2}{*}{$\begin{array}{l}\text { 6- I feel tight and pressed in my } \\
\text { head }\end{array}$} & Father & 7 & $15 \%$ & 22 & $46 \%$ & 16 & $33 \%$ & 3 & $6 \%$ & \multirow[t]{2}{*}{1.720} & \multirow{2}{*}{$\begin{array}{l}0.632 \\
(\mathrm{NS})\end{array}$} \\
\hline & Mother & 6 & $13 \%$ & 27 & $56 \%$ & 14 & $29 \%$ & 1 & $2 \%$ & & \\
\hline \multirow{2}{*}{$\begin{array}{l}\text { 7- Did you have a feeling of cold } \\
\text { periods and hot periods }\end{array}$} & Father & 9 & $19 \%$ & 15 & $31 \%$ & 21 & $44 \%$ & 3 & $6 \%$ & \multirow[t]{2}{*}{13.368} & \multirow[t]{2}{*}{$0.004^{*}$} \\
\hline & Mother & 2 & $4 \%$ & 9 & $19 \%$ & 37 & $77 \%$ & 0 & $0 \%$ & & \\
\hline
\end{tabular}


Mosul Journal of Nursing, Vol. 7, No. 2, 2019 ( 63-74 )

Table -4 anxiety/insomnia(GHQ-B) for father and mother

\begin{tabular}{|c|c|c|c|c|c|c|c|c|c|c|c|}
\hline anxiety/insomnia & & No. & $\%$ & No. & $\%$ & No. & $\%$ & No. & $\%$ & $\mathbf{X}^{2}$ & $\begin{array}{c}\mathbf{P}_{-} \\
\text {Value }\end{array}$ \\
\hline \multirow[t]{2}{*}{ 8- Lost much sleep over worry? } & Father & 11 & $23 \%$ & 4 & $8 \%$ & 24 & $50 \%$ & 9 & $19 \%$ & \multirow[t]{2}{*}{8.089} & \multirow[t]{2}{*}{$0.044 *$} \\
\hline & Mother & 7 & $15 \%$ & 15 & $31 \%$ & 19 & $39 \%$ & 7 & $15 \%$ & & \\
\hline \multirow{2}{*}{$\begin{array}{l}\text { 9- Had difficulty in staying asleep } \\
\text { once you are off? }\end{array}$} & Father & 10 & $21 \%$ & 10 & $21 \%$ & 8 & $16 \%$ & 20 & $42 \%$ & \multirow[t]{2}{*}{3.238} & \multirow{2}{*}{$\begin{array}{l}0.356 \\
(\mathrm{NS})\end{array}$} \\
\hline & Mother & 8 & $16 \%$ & 18 & $38 \%$ & 6 & $13 \%$ & 16 & $33 \%$ & & \\
\hline \multirow{2}{*}{$\begin{array}{c}10 \text { - He constantly felt under } \\
\text { pressure? }\end{array}$} & Father & 16 & $33 \%$ & 7 & $15 \%$ & 12 & $25 \%$ & 13 & $27 \%$ & \multirow[t]{2}{*}{7.924} & \multirow[t]{2}{*}{$0.048 *$} \\
\hline & Mother & 8 & $17 \%$ & 8 & $17 \%$ & 24 & $50 \%$ & 8 & $16 \%$ & & \\
\hline \multirow{2}{*}{$\begin{array}{l}\text { 11- Are you nervous and your } \\
\text { mood is bad? }\end{array}$} & Father & 23 & $48 \%$ & 10 & $21 \%$ & 9 & $19 \%$ & 6 & $12 \%$ & \multirow[t]{2}{*}{6.769} & \multirow[t]{2}{*}{$0.080 *$} \\
\hline & Mother & 14 & $29 \%$ & 21 & $44 \%$ & 6 & $13 \%$ & 7 & $14 \%$ & & \\
\hline \multirow{2}{*}{$\begin{array}{l}\text { 12-? Been getting scared or } \\
\text { panicky for no good reason? }\end{array}$} & Father & 11 & $23 \%$ & 18 & $38 \%$ & 15 & $31 \%$ & 4 & $8 \%$ & \multirow[t]{2}{*}{11.890} & \multirow[t]{2}{*}{$0.008 *$} \\
\hline & Mother & 20 & $42 \%$ & 23 & $48 \%$ & 3 & $6 \%$ & 2 & $4 \%$ & & \\
\hline \multirow{2}{*}{$\begin{array}{c}\text { 13-Found everything getting on top } \\
\text { of you? }\end{array}$} & Father & 8 & $16 \%$ & 10 & $21 \%$ & 10 & $21 \%$ & 20 & $42 \%$ & \multirow[t]{2}{*}{5.619} & \multirow{2}{*}{$\begin{array}{l}0.132 \\
(\mathrm{NS})\end{array}$} \\
\hline & Mother & 6 & $13 \%$ & 10 & $21 \%$ & 20 & $41 \%$ & 12 & $25 \%$ & & \\
\hline \multirow{2}{*}{$\begin{array}{l}\text { 14- You feel tense or tense all the } \\
\text { time? }\end{array}$} & Father & 17 & $35 \%$ & 16 & $33 \%$ & 9 & $19 \%$ & 6 & $12 \%$ & \multirow[t]{2}{*}{11.324} & \multirow[t]{2}{*}{$0.010 *$} \\
\hline & Mother & 7 & $15 \%$ & 15 & $31 \%$ & 23 & $48 \%$ & 3 & $6 \%$ & & \\
\hline
\end{tabular}

Table -5 social dysfunction(GHQ-C) for father and mother

\begin{tabular}{|c|c|c|c|c|c|c|c|c|c|c|c|}
\hline social dysfunction & & No. & $\%$ & No. & $\%$ & No. & $\%$ & No. & $\%$ & $\mathbf{X}^{2}$ & $\begin{array}{l}\mathbf{P}_{-} \\
\text {Value }\end{array}$ \\
\hline \multirow{2}{*}{$\begin{array}{l}\text { 15- Have you been able to } \\
\text { continue your work and focus on } \\
\text { it? }\end{array}$} & Father & 8 & $17 \%$ & 11 & $23 \%$ & 23 & $48 \%$ & 6 & $12 \%$ & \multirow[t]{2}{*}{5.896} & \multirow[t]{2}{*}{0.117} \\
\hline & Mother & 17 & $35 \%$ & 6 & $13 \%$ & 17 & $35 \%$ & 8 & $17 \%$ & & \\
\hline \multirow{2}{*}{$\begin{array}{l}\text { 16- Been taking longer over the } \\
\text { things you do? }\end{array}$} & Father & 6 & $12 \%$ & 22 & $46 \%$ & 7 & $15 \%$ & 13 & $27 \%$ & \multirow[t]{2}{*}{0.154} & \multirow[t]{2}{*}{0.985} \\
\hline & Mother & 7 & $15 \%$ & 22 & $46 \%$ & 6 & $12 \%$ & 13 & $27 \%$ & & \\
\hline \multirow{2}{*}{$\begin{array}{l}\text { 17- Felt on the whole you were } \\
\text { doing things well? }\end{array}$} & Father & 14 & $29 \%$ & 24 & $50 \%$ & 9 & $19 \%$ & 1 & $2 \%$ & \multirow[t]{2}{*}{18.099} & \multirow[t]{2}{*}{$0.000 *$} \\
\hline & Mother & 23 & $48 \%$ & 5 & $11 \%$ & 17 & $35 \%$ & 3 & $6 \%$ & & \\
\hline
\end{tabular}


Mosul Journal of Nursing, Vol. 7, No. 2, 2019 ( 63-74 )

\begin{tabular}{|c|c|c|c|c|c|c|c|c|c|c|c|}
\hline \multirow{2}{*}{$\begin{array}{l}18-\text { Been satisfied with the way } \\
\text { you've carried out your tasks? }\end{array}$} & Father & 15 & $31 \%$ & 20 & $42 \%$ & 7 & $15 \%$ & 6 & $12 \%$ & \multirow[t]{2}{*}{0.263} & \multirow{2}{*}{$\begin{array}{l}0.967 \\
(\mathrm{NS})\end{array}$} \\
\hline & Mother & 15 & $31 \%$ & 22 & $46 \%$ & 6 & $13 \%$ & 5 & $10 \%$ & & \\
\hline \multirow{2}{*}{$\begin{array}{l}\text { 19-Felt you are playing ausefull } \\
\text { part of things? }\end{array}$} & Father & 6 & $13 \%$ & 26 & $54 \%$ & 10 & $21 \%$ & 6 & $12 \%$ & \multirow[t]{2}{*}{21.586} & \multirow[t]{2}{*}{$0.000 *$} \\
\hline & Mother & 10 & $21 \%$ & 5 & $11 \%$ & 17 & $35 \%$ & 16 & $33 \%$ & & \\
\hline \multirow{2}{*}{$\begin{array}{l}\text { 20- Felt capable of making } \\
\text { decisions about things? }\end{array}$} & Father & 9 & $19 \%$ & 19 & $40 \%$ & 17 & $35 \%$ & 3 & $6 \%$ & \multirow[t]{2}{*}{6.398} & \multirow{2}{*}{$\begin{array}{l}0.094 \\
(\mathrm{NS})\end{array}$} \\
\hline & Mother & 5 & $11 \%$ & 13 & $27 \%$ & 29 & $60 \%$ & 1 & $2 \%$ & & \\
\hline \multirow{2}{*}{$\begin{array}{l}\text { 21- been able to enjoy your } \\
\text { normal day - to day activities? }\end{array}$} & Father & 3 & $6 \%$ & 7 & $15 \%$ & 29 & $60 \%$ & 9 & $19 \%$ & \multirow[t]{2}{*}{12.914} & \multirow[t]{2}{*}{$0.005^{*}$} \\
\hline & Mother & 1 & $2 \%$ & 23 & $48 \%$ & 17 & $35 \%$ & 7 & $15 \%$ & & \\
\hline
\end{tabular}

Table-6 depression(GHQ-D) for father and mother

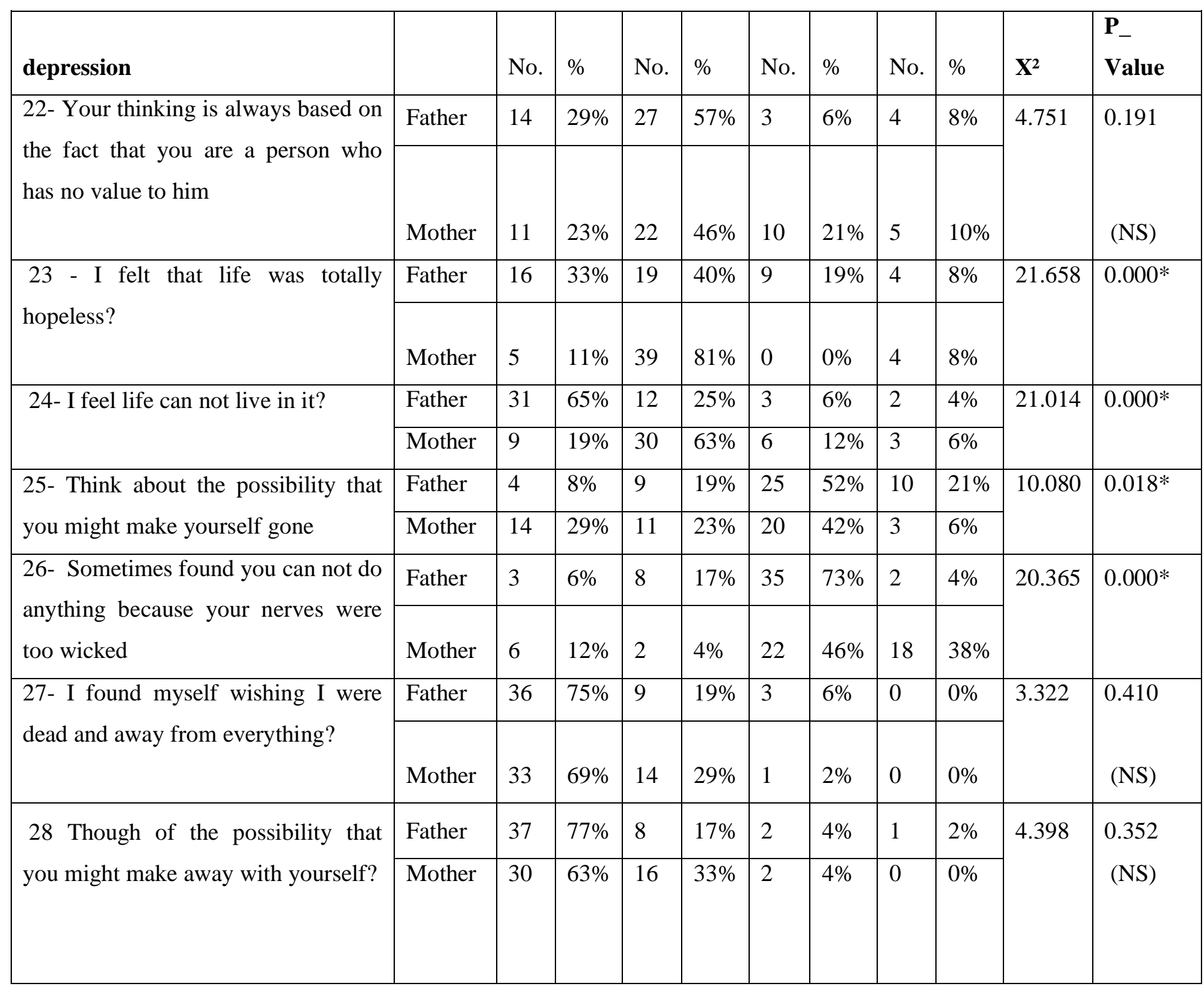




\section{Mosul Journal of Nursing, Vol. 7, No. 2, 2019 ( 63-74 )}

\section{Discussion :}

Having a physically-impaired child in the family is one of many factors that can flounce the mental health of the family (kushalnagar et al, 2007).

The finding of the present study showed in the table (1) the population of this study was parnteal for 48 deaf children have (CI), female have (CI) was $54 \%$ male have CI was $46 \%$, some studies showed the gender-difference of 162 deaf children is obtainable and linked to the grade of auditory damage and the etiology of their deafness, The population of that hearing impaired and deaf people consists of an average of $54 \%$ men and $46 \%$ women This result was presented the sample is commonly female (momohamadi,2005). age of child was (above 5 years54\%), showed a delay of (CI) for child this result, agree there are several reasons why parents make late decisions in cochlear implantation most important Lack of awareness (what to do and where to go ?), Fully aware but financial problem. other studies mean age of deaf children was 72 months, The duration of cochlear implantation was 1- 124 months. ( shenal kothari, 2015). second child $42 \%$. The opinion that this percentage is not important may be the child or the second because the causes of hearing loss are many, including money related to the disease, including what is caused by illness or medical error.

Table -2 show father worker was $48 \%$, mother house wife was 65\%, In 2005, 278 million people worldwide suffered moderate or severe hearing loss in both ears, with $80 \%$ of the people living in low- and middle-income countries.( Nouri,M, 2017 ). For the first time in the Middle East, the prevalence of hearing impairment was reported $5.5 \%$ and 36.06 in 1000 population in Oman in 2004. (alkhabori, 2007).

Age of father (25-30) was $56 \%$, mother age (under25) was $52 \%$

Marriage of girls at the age of 18 and marriage for males is usually 22 years old Common in Iraq and the Middle East.

Other studies have shown the mean age of the mothers population was $29.5 \pm 5.5$ years. Most of them were primary school graduates $(59.0 \%)$ and unemployed (80.0\%) with low levels of monthly income (85\%),( Enes Yiğit, 2018)

Table -3 show had a significant effect on the physical symptoms in the second paragraph in (Been feeling in need of a good tonic? For the mother, and this shows that the mother needs more tonic drugs than the father because the mother is a great responsibility and must always communicate with the child with patience and that because the rehabilitation of the child to understand speech and pronunciation needs a long time. The most significant burden of the disease was the treatment cost $(30,0 \%)$,followed by workrelated problems $(25.0 \%)$ and problems with the care of other children (15.0\%) (yigit, 2018). The parents 'misery towards their deaf children results in parents' tension due to initial diagnosis, increasing economic difficulties, difficulty communicating with their children, feelings of stigma and loneliness and adapting to their basic or secondary needs..( Suprakash,2014), the group of deaf CI children 


\section{Mosul Journal of Nursing, Vol. 7, No. 2, 2019 ( 63-74 )}

mothers relate substantially more somatic and anxiety symptoms than fathers(kobsko,2013).

Another studies showed found significant difference between worry levels of mothers and fathers both before and after cohlear implant (CI). This result may be of course due to gender, but it is probably due to the role of motherhood. As women carry the child and give birth they form a bond with the child much sooner than the father.( Kezban,2013)., paragraph (7- about been having hot or cold spelles? ) was significant, The body is naturally excreted with Adrenaline in the blood when feeling high degree of tension and anxiety, in order to narrow the peripheral vessels in the limbs, and thus maintain the body's energy to be used by the body to defend himself in the event of danger.

Table -4 show the significant in paragraph $8,10,11,12,14$ in (Lost much sleep over worry He constantly felt under pressure? Are you nervous and your mood is bad? Fear or panic was felt for no good reason, You feel tense or tense all the time.

This explains of the daily problems faced by parents, especially mothers, because of the child's style and economic situation, where parents are always watching the child during the playing and the continuous movement and keenness on the cochlea for fear of loss or damage

Problems were categorized in 9 domains: implant drawbacks, communication difficulties, child's behavior and character, socialization, habilitation demands and parenting role, financial difficulties, services, educating others and/or advocacy, and academic concerns(zaidman, 2008).

Table- 5 show significant in pargraph 23,24,25,26, (I felt that life was totally hopeless I feel life can not live in it? , Sometimes found you can not do anything because your nerves were too wicked?, Think about the possibility that you might make yourself gone?)

As a result of the moments that pass the parents will be desperate to the farthest and when they think about the future of the child, and that the child's vision shows signs of depression, isolation, loneliness.

The psychological reaction of the parents to the diagnosis of deafness in their child typically includes feelings of grief, helplessness, guilt and anger. In addition, given the central role of hearing to human communication, a sense of isolation within the parent-child dynamic is inevitable. (Mellon NK,2009). The task of parenting becomes most difficult while opting for an appropriate amplification device,therapy program or a school program for their child with hearing loss(Mohamed,A ,2013). In another study, she agreed that the burden on the mother is more than the problems and diseases that affect the father. This comes from the close relationship between the mother and her child, as well as the divorced mothers or those who have lost their husbands, who are more prone to problems than the mothers who suffer.(alhadidie, 1992). The rest of the paragraphs showed no significant statistical differences indicating that parents' pressure decreased after transplantation, his is 


\section{Mosul Journal of Nursing, Vol. 7, No. 2, 2019 ( 63-74 )}

consistent with the ( Hintermair 2014) study involving (213) mothers and (213) fathers of children with disabilities

The results indicated a decrease in parental pressure, with sources of personal and social support.

\section{Conculsion}

Cochlear implant is one of the treatments for deafness. Parents of children with hearing loss have normal somatic moods of frustration, challenge or anxiety.

According the study show had a significant effect on the physical symptoms in the second paragraph in (need of tonic) paragraph (7feeling of cold periods and hot periods? ) was significant, show the significant in paragraph $8,10,11,12,14$ in insomnia and lack of sleep?, And the constant feeling that they are burdened with heavy burdens and constant pressure? Emotion and bad mood? Been getting scared or panicky for no good reason, Been feeling nervous or strung-up all the time show significant in pargraph 23,24,25,26, (And despair of life, and there is no benefit from living there? found at times you couldn't do anything because your nerves were too bad? The idea of emigration and leaving the family remains in my mind.

\section{Recommandation :}

Preparing a comprehensive extension program that is suitable for the size of the problem experienced by parents and families through psychological, social and financial support programs, participation of specialists and professionals, families of children with hearing disabilities, and the development of suitable solutions for them

Being interested in developing a child's language helps parents get rid of their anxiety, Provide advanced rehabilitation centers within the governorate and be more than a center rehabilitation and training of staff working in the centers of rehabilitation, Make the parents communicate fully with the manufacturers of the cochlear and make the center of the company in each province, providing the spare tools for planting,

Working on the opening of specialized centers for cochlear implantation to reduce cost. Help parents to learn and learn about the methods that help them to coping and adapt to the person with hearing disabilities.

Based on the results of this study, we may hold briefing classes just after the operation of the child to emphasize satisfaction and mental health of their parents. It is also recommended more studies should be done with more participants and in other clinics and hospitals. In light of the lack of comprehensive and accurate statistics for the disabled in general and hearing impaired in particular, the researcher recommends to the competent institutions, especially the Central Statistical Organization of Iraq, a comprehensive survey of all categories of disability in Iraq to find out the real size of the problem

The Iraqi media should contribute to the dissemination of the culture of care for people with special needs, especially people with hearing disabilities, and to allocate psychological programs to discuss the 


\section{Mosul Journal of Nursing, Vol. 7, No. 2, 2019 ( 63-74 )}

problems of people with special needs and provide appropriate extension services.

\section{References}

Alhadedi, 1992, Guidance for Families of Children with Special Needs, United Arab Emirates, Al Falah Library for Publishing and Distribution,page 15,93, 69,62.

alkarkh ,health directrate bagdad web,2018

Alkhbori M, KandKra R., (2007), unilateral hearning impairment in aman, acommunity based cross - sectional study, Ear Nose Throt J., 86(5): 279

Alsherbeni, Z, A special child between disabilities and syndromes - Definition And diagnosis, Cairo, Arab Thought House alwaten , news paper ,24 March, 2016 Beadle EAR, McKinley DJ, Nikolopoulos TP, Brough J, O'Donoghue GM, Archbol SM. Long-term functional outcomes and academicoccupational status in implanted children after 10 to 14 years of cochlear implant use. Ontology \& Neurotology. 2005;26:1152-1160

Besharat MA, Tashk A, Rezazadeh SM. ,Nomination of satisfaction marriage and mental health based on coping styles. The Journal Contemporary Psychotherapy, 1: 48$56 ., 2006$

British cochlear implant group, quality standared s cochlear implant, services for children and adults, April , 2018

Fatemeh Saghafi1, Zainabolhoda Heshmati2, Technical Journal of Engineering and Applied Sciences, 2013-3-16/1855-1861
Filipo R, Bosco E, Barchetta C., Cochlear implant in deaf children and adolescent: effect on family schooling and personal wellbeing,1997, International Journal of Pediatric Otorhinolaryngology

Garry VF, Harkins ME, Erickson LL, Long Simpson LK, Holland SE, Burroughs BL. Birth defects, season of conception, and sex of children born to pesticide applicators living in the Red River Valley of Minnesota, USA. Environ Health Perspect 2002,3:441-9

Hintermair,M (2014): Parental Resources, Parental Stress, and Socioemotional Development of Deaf and Hard of Hearing Children, Journal of Deaf Studies and Deaf Education, Volume 11, Issue 4, Pp. 493-513.

Holmes, L.. What is Mental Health? In Menta Health Resources. Retrieved March 16, mentalhealth.miningco.com, 2003

Kezban, M, Kaya,E, etal, Parental Anxiety and Influential Factors in the Family with Hearing Impaired Children Before and After Cochlear, Implantation, Int. Adv. Otol. 2013; 9:(1) 46-54 Kush alanager P, Krull K , Hanny J, et al, 2007, intelligence, parental depression, and behavior adaptability in deaf children being considered for cochlear implantation, journal of Child and family studies 15:37-92

Leonardi $\mathrm{M}$ et al. MHADIE Consortium,The definition of disability: what is in a name? Lancet, 2006,368:1219-1221

Mary , Flaherty, Australasian journal of special education, volume 39, issue1, july, 2015 ,pp 67-84

Mellon NK. Parental Response to the Diagnosis of Hearing loss. In: Niparko JK, 2nd, In Cochlear Implants: Principles and 


\section{Mosul Journal of Nursing, Vol. 7, No. 2, 2019 ( 63-74 )}

practices.Philadelphia: Lippincott, Williams \& Wilkins; 2009. p 147-150

Mirahmadizadeh AR, Nakhaeeamrodi N, Tabatabaee SM, Shafieian R. In Persian 2003, Marriage satisfaction and introduction of the effective actors, Case study: Shiraz city. Thought \& Behavior J.,2003 8:56-63

Mishra AK, Gupta R. Disability index: a measure of deprivation among the disabled. Economic and Political Weekly2006,41:40264029 ,

Mohamed, A, Farhadi ,M, et al, the prevalence of hearning impairment by age and agnder population - based study, Iranian journal of public health ,2017, sept.,46(9) , 1237,1246

Mohamadi MR, Davodiyan H, Noorbala AA.et al. 2005. An epidemiological survey of psychiatric disorders in Iran. Clinical Practice and Epidemiology in Mental Health, 1:16

Nouri,M, College of Education for Human Sciences, university of babelon, Key facts and prevalence ratios, 2017 , lecture

Overbeek G, Vollebergh W, Groaf RD, Scholte R, Kemp RD, Engels R. 2006. Longitudinal associations of marital quality and marital dissolution

Richter B, Sphan C, Zschock I, Leuchter M, Laszige R, Lohle E. Psychological stress, knowledge and treatment expectation of parents with a child managed by cochlear implant. 2000, HNO. 48:675-83

Seligman MEP. 2001. Positive psychology: An introduction. Psychologist, 55:5-14

Shenal Kotharai, Nirnay Kumar, pediatric cochlear implantion - why the delay indian J, otolaryngol head Neck surgery, 2015, june 67(2):165-169

Yigit,E, Tuna, D, et al, atisfaction with Life among Mothers of Pediatric Cochlear Implant Candidates: The Impact of Implant Operation and Sociodemographic Factors, J Int Adv Otol 2018 Aug; 14(2): 202-20

zaidman-zait,A, (2008).every day problems and stress faced by parents of children with a cochlear implant, rehabilitation psycology 53(2), 139-152,APA

zuna, N., Summers, J.A, Turnbull, A.P., Hu, $\mathrm{X}$., \& Xu, S. -Enhancing the quality of life of people with intellectual disabilities: Theorizing about family quality of life (2010). with the incidence of DSM-III $-\mathrm{R}$ disorders. J. Fam. Psycho2006, 20:284-91 